\title{
THE IMPACT ANALYSIS OF COORDINATION AGAINST THE EFFECTIVENESS OF SERVICE ONE-STOP CORPORATE ADMINISTRATION SYSTEM AREA AT PANDEGLANG, BANTEN PROVINCE
}

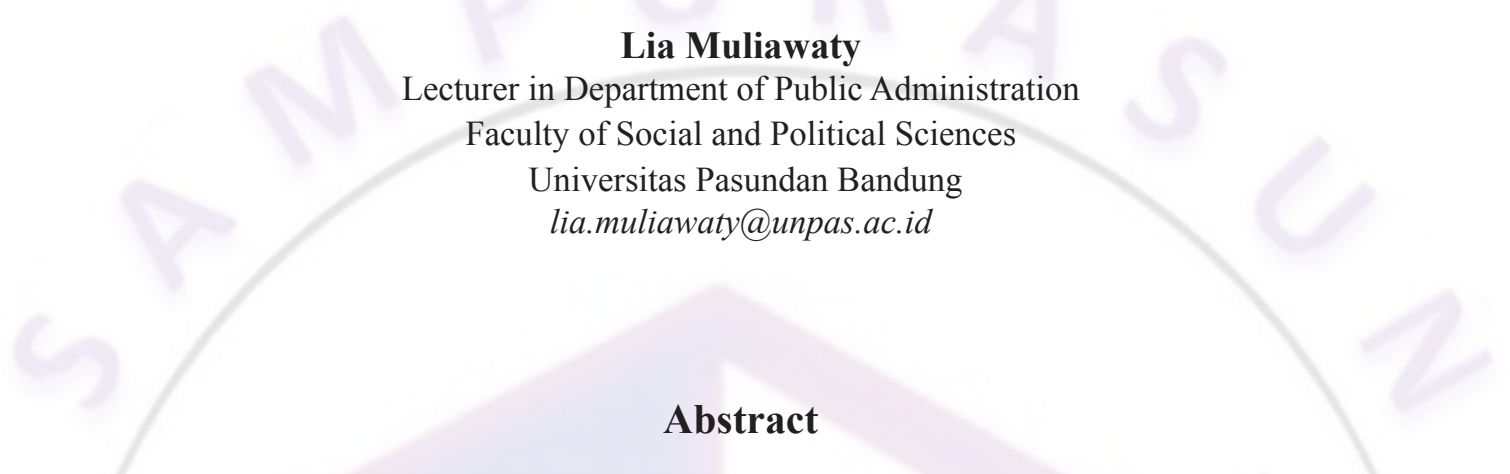

The main problem in this research is the effectiveness of the service of motor vehicle registration number of service one-stop corporate administration system area at Pandeglang, Banten Province was low, allegedly caused by the coordination between each unit or part has not run optimally. The method used in this research is descriptive analysis by using path analysis (path analysis) that is by seeing how big influence and independent variable to dependent variable, either influences directly or indirect influence. With this design will be measured directly or indirectly the coordination influence expressed in 7 (seven) dimensions, namely the existence of agreement and unity of understanding, the existence of the agreement on the activities, the existence of obedience, the exchange of information, the presence of coordinators who can lead, the existence of information from Various parties. The results of the research can be found that the effectiveness of Motor Vehicle Tax Service is with the percentage is $98.0 \%$. This means that the coordination is very dominant and decisive towards the increase of tax service. However, there are also other factors that are not examined (epsilon) but determine the tax service of $2.0 \%$.

\section{Keywords: good coordination improves effective service.}

\section{Introduction}

One of the elements of total reform is the demand for wide-ranging autonomy to the districts and municipalities. Such demands are reasonable, at least for two reasons: 1) too large central government interventions in the past have led to problems of low capability and effectiveness of local governments in promoting development and democratic life in the region, 2) demands for autonomy as well Emerged as an answer to enter the new game era that brings new rules on all aspects of human life in the future. In this era where globalization cascade is widening, the government will increasingly lose control on many issues, such as on international trade, information and ideas, and financial transactions

The enactment of Law no. 22 year 1999 Jo.No. 32 of 2004 on Regional Government and Law no. 25 years 1999 Jo. No. 35 year 2004 about the Central and Regional Financial Balance is the starting point for local autonomy. The main mission of the two laws is fiscal decentralization, which is expected to produce two tangible benefits: first, encourage increased participation, initiative, and community creativity in development, and encourage equitable distribution of development outcomes across the region. Second, improving the allocation of productive resources through shifting the 
role of public decision-making to lower levels of government.

Law no. 22 year 1999 Jo. NO. 32 of 2004 on Regional Government is one of the juridical grounds for the development of local autonomy in Indonesia. The law states that the development of autonomy in regencies and municipalities is carried out by taking into account the principles of democracy, community participation, equity and justice, and attention to regional potentials and diversity.

Autonomy given to districts and municipalities is implemented by granting broad, real and accountable local authorities to the proportional government. This means that the transfer of responsibilities will be followed by equitable sharing arrangements, and utilization and national resources, as well as the balance of central and regional finances.

The development of the State Administration today in both developed and developing countries leads to increased efficiency and professionalism of public services. All that moves in public administration must be arranged rationally, efficiently and dynamically in serving the community. Especially in the current era of globalization must be seen in the context of how to optimize the functions of government in providing services to the public because the presence of government is the desire of the community and one of the main task of the government is the main service to the public. Therefore, the government must prepare the concept of service quality and can be accountable and trying to minimize customer dissatisfaction by providing excellent service, both central and regional.

One of the efforts to increase the revenue of PAD (local revenue) sources can be done, among others, by increasing the revenue of the regional tax and retribution, either through intensification or extensification of levies. This is stipulated in Law Number 34 Year 2000 Jo. NO. 28 of 2009 on Regional Taxes and Levies. This law sets out the main provisions which provide guidance on policies and direction for regions in the implementation of tax and levy collection, as well as establishing regulations to ensure the application of the general procedures of local taxation.

In accordance with Law Number 28 of 2009 , state taxes submitted to provinces consist of:

1. Motor Vehicle Taxes;

2. Name return tax of Motor Vehicle;

3. Motor Vehicle Fuel Tax;

4. Surface Water Tax; and

5. Cigarette Tax.

This research will discuss about PKB and BBNKB, which is related to the payment of Traffic Accident Fund and the validation of vehicle registration every year. The PKB / BBNKB levy system is implemented at SAMSAT Office, since SAMSAT is one of the government agencies where in performing its duties using an integrated system by uniting the process of completion of Vehicle Registration Certificate (STNK) with the payment of Vehicle and Customs Taxes Behind Motor Vehicle Name (PKB and BBNKB) as well as Mandatory Contribution of Road Traffic Accident Fund (SWDKLLJ).

SAMSAT was formed based on three joint decisions between the Minister of Defense / Commander of the Armed Forces, the Minister of Finance and the Minister of Home Affairs with the Pol.Kep / 13 / X11 / 1976 Number, Jo. INS / 03 / M / / X / 1999, No. 29/1999 on the enhancement of cooperation between the Government of the First Level Region, the Regional Police Command and the Apparatus of the Ministry of Communities in the framework of increasing the regional income, in particular the CLA. The contents of the decision include:

1. Whereas in the framework of efforts to increase the security, and controlling the implementation of the collection of local taxes, especially the collection of PKB and BBNKB, it is necessary to further enhance cooperation between the gubernatorial apparatus to the regional and Regional Police Command officers throughout Indonesia.

2. That the increasing number of motor vehicles, then the increase of revenues in this sector should be balanced with efficiency efforts in both system, administration and policy of collection. 
3. Whereas the collecting of PKB and BBNKB and Road Traffic Accident Fund is very closely related to the expenditure of STNK, so the research on the debt of vehicle registration every year will also mean the research of repayment of Tax on Vehicle Tax and Redemption of Road Traffic Accident Fund.

4. That in order to improve the best service to motor vehicle owners, it is necessary to simplify the cam to pay its levies in relation to motor vehicles, hence it is necessary to have a place (counter) where the owner of the motor vehicle at once can complete the payment of administrative costs Motor vehicles, taxes and traffic accident funds.

(Inbers Number Pol.Kep / 13 / XII / 1976. Jo INS / 03 / MI / X / 1999, Number 29 of 1999).

The three government agencies above each delegate to the subordinate ministry to handle operational tasks in the field. Defense Minister / Armed Forces Commander delegated to the Police of the Republic of Indonesia (POLRI), the Minister of Finance delegated to PT. JasaRaharja Insurance and the Minister of Home Affairs delegate to the Regional Financial Management and Asset Office, each of which opens branches in each District, with the task

1. Regional Financial Management and Asset Office, assigned to collect PKB and BBNKB.

2. Police, assigned to provide registration services and identification of Vehicle Ownership Proof (BPKB), vehicle registration and Motor Vehicle Number Plate (PNKB)

3. PT. AsuransiJasaRaharja, is responsible for collecting the Mandatory Donation of Road Traffic Accident (SWDKLLJ). (Inbers Number Pol.Kep / 13rx1111 976 Jo.INS / 03 / MHX / 1999 Number 29 of 1999)

Motor Vehicle Tax collected as a source of regional income, the authority is in the hands of the Governor which includes the registration / registration, determination, deposit, book keeping and reporting, objection and appeal, billing, correction, cancellation, reduction, removal or reduction of administrative sanctions and excess payment All implemented by the Regional Office.

Efforts to increase security and controlling the implementation of the collection of local taxes, especially PKB, should be emphasized cooperation between the apparatus of the Governor of the Head of Region with the apparatus of the Regional Police Command of the Republic of Indonesia. The necessity Cooperation that is because the work done UPT through PKB / BBNKB section related to police work.

The results obtained from PKB's income are under the Coordination of the Regional Financial Management and Asset Service, the Regional Financial Management and Asset Office in performing their duties and to improve the services to the community, forming technical units directly in contact with the community. Implementing units of local government policy from the Regional Financial and Asset Management Office are known as Technical Implementation Unit (UPT) spread over 12 Units throughout Banten. UPT is established based on Banten Province Regulation no. 3 of 2008 on the Establishment of Organization and Working Procedures of Banten Province Office. Technical Implementation Unit (UPT) has the main duty to perform services, development, conservation and conservation training in accordance with the policy of the Governor.

Certificate of Vehicle Number (STNK) received by the owner of a motor vehicle is a proof of payment of Motor Vehicle Tax (PKB \& BBNKB) and is the authority of the police, while the license plate received serves as a tax and service officer, whose validity period is up to number, month And the year listed on the license plate. Thus the affairs of letters and tax receipts relating to ownership of motor vehicles will be simpler.

SAMSAT in carrying out its duties involves three different agencies namely Provincial Finance and Asset Management Office of Banten, Police, PT. Asuransi Jasa Raharja, therefore it is necessary to coordinate to discipline the operational activities in the field. Implementation of coordination between 
the Office of Management of Finance and Regional Assets Banten Province, Police, PT. JasaRaharja Insurance is not just about the issue of communicating information or forming appropriate administrative structures, but also about the more fundamental issue, namely the exercise of the exercise of power. This is the same as the implementation of guidance that is guiding, nurturing, directing and moving people to want to cooperate to achieve goals. The complex organizational structure consists of three different agencies, where each agency carries its own flag will lead to increasing difficult communication problems to obtain good coordination. Difficulties in coordination that will arise, both horizontal and vertical. In line with PandapatSugandha (1991: 12-13) that: "Coordination is integrating motion of all potential and organizational units of different functions in order to really lead to the goal to facilitate the achievement of goals".

Implementation of coordination and direction is an integral that can not be separated from each other and can affect the effectiveness of employees. Furthermore, The Liang Gie (1982: 108) put forward the notion of effectiveness as follows: "Effectiveness is a state that contains an understanding of the occurrence of a desired effect or effect". Integration of activities through coordination of course will help realize the objectives of each agency effectively. To support these objectives to be achieved, each agency has the authority and tasks that can be accountable to their respective bosses. However, such powers and responsibilities need to be co-ordinated together as long as it relates to the technical implementation of SAMSAT. Therefore, SAMSAT in carrying out its performance is nurtured and guided continuously by the SAMSAT Trust Team which has been appointed based on the Decree of Banten Governor.

Based on the results of observation and assessment of the field that researchers do on the One Block Roof Administration System PandeglangBanten Province, it was found the problem of service effectiveness is still low, it is indicated by indicators of the problem as follows:

1. Low work quality of staff. Example: Employee often mistakes in typing the name of the owner on the vehicle tax evidence. This is due to the inaccuracy of employees in typing was so that the quality of vehicle registration produced low.

2. There is inaccuracy of time in the completion of work to the taxpayer. For example in the management of payment of Motor Vehicle Tax which should be completed within one day but in reality up to 2 days. This is partly due to the available service counter is not sufficient.

The problem mentioned above, allegedly caused by the coordination of employees who have not run optimally. Based on the above explanation, the researcher is interested to conduct a study and in-depth study with the title of Analysts Impact Coordination on Service Effectiveness of Pandeglang Area ManunggalOne Roof Administration System of Banten Province.

Robbins in Udaya (1994: 4) suggests that an organization is a radar-coordinated social entity, with a relatively identifiable boundary. Which work continuously to achieve a common goal or goals. And this understanding, that within the organization there are management functions such as coordination, as proposed by Luther Gulick that Management functions consist of Planning, Organizing, Staffing, Directing, Coordinating, Reporting. Budgeting or abbreviated (POSDCORB), in line with that Gie (1989: 13), the same opinion, such as the coordination (coordination), is one of the management functions.

Achieving organizational goals, both governmental organizations and private organizations, are often divided into units with different powers and responsibilities. So that the distinction creates a specialization in the work. But in order for the main purpose of the organization to be achieved effectively and efficiently, coordination is required. This is in line with opinion. Sugandha, (1996: 12-13) stating that: Coordination is the unification of the motion of all potential and organizational units or organizations of different functions in order to properly target the same objective in order to facilitate its efficient appraisal.

The above opinion that coordination is the unity of motion in different units within an 
organization so that the work leads to the goal of achieving goals. In line with the above opinion, The Liang Gie (1989: 15) says that: Coordination is the activity of connecting people and tasks Tasks so as to ensure the unity or alignment of decisions, Wisdom, action, steps, attitudes and prevented from occurring Contradiction, chaos, twin, and void action.

Taking apart activities apart from each organizational unit is not an easy task, each unit has a difference from both the members' behavior, the goals and functions of each organizational unit, for which a leader who is able to coordinate is required. This is in accordance with the opinion of Farland (1979: 186), namely: Coordination is the process by witch managers achieving integrated patterns of group and individual effort. To coordinate is to develop unity of action in common purpose. (Coordination is the process by which the leader strives to achieve an integrated pattern of individual groups and efforts.) Coordination is developed to unify activities in achieving common goals).

The above definition explains that coordination has characteristics that are, Coordination is the responsibility of the leadership, the continuous process, the regular arrangement of the group effort, the concept of unity of action and the purpose of coordination is a common goal.

Mooney in Sutarto (2000: 141) argues that: Coordination as the achievement of orderly effort effort, and unity of action in the pursuit of a common purpose (coordination as the achievement of group effort on a regular basis and unity of action in achieving common goals).

Farland and Mooney's opinion, there is a common view of coordination, which in essence is coordination is the process of uniting the activities of various organizational units to achieve goals. But Farland emphasizes the importance of leadership as a coordinator who will develop activities to achieve the goals of an organization, while Mooney only emphasizes the substance of the coordination without listing the elements of leadership.

The administrative system is the second mechanism for coordinating the direction of the various activities, since the lion's share of the coordinative effort within Organized organization on routine work flow in the horizontal line. The administration system outlines a formal procedure for carrying out so many coordinated routine jobs automatically.

Many job-completion procedures, such as memouse, disposition, helpcoordinatedifferent activities of different units of implementation. To some extent such a procedure can be a routine activity, and therefore does not need to be specifically structured. For non-routine and non-programmed activities, special units such as committees may be required in order to incorporate such activities

The second type is coordination through voluntary means. Many activities can be coordinated on the basis of the will and ability of a person or group to freely find ways to integrate their activities with other parts of the organization. Realizing this kind of coordination is the most important effort for a leader even though it is also a difficult problem. The requirement is that everyone has sufficient knowledge of organizational goals, understanding information about special problems of coordination, and motivation to do things in his own way and judgment.

Measure the effectiveness of coordination. Sugandha (2006: 47) suggests that the element of coordination requires the following:

1. There is an agreement and unity of understanding on the objectives that must be achieved as the direction of joint activities.

2. There is agreement on the activities or actions to be undertaken by each party, including its targets and schedule.

3. The existence of the obedience or loyalty of each party to their respective duties and schedules that have been determined.

4. Existence of mutual exchange of information from all parties who cooperate on the activities and the results at a certain time including the problems faced by each unit.

5. There is a coordinator who can lead and mobilize and monitor the cooperation and lead problem solving together.

6. There is information from various parties that flows to the coordinator so that the coordinator can monitor the whole implementation of cooperation and 
overcome the problems that are faced by all parties.

7. There is mutual respect for the functional authority of each party so as to create a spirit to help each other.

Steers in Jamin (2004: 151) argue that: "effectiveness relates to productivity and efficiency, where effectiveness and efficiency are indicators of productivity". Effectiveness refers to the achievement of targets in quantity, quality and timeliness. A target program is achieved the higher level of effectiveness. Effectiveness is related to quality, while efficiency is a reflection of the relationship between input and output that is quantity. Further Steers in Jamin (2004: 151) states that the effectiveness of measurement services is seen from:

1. Quality Accuracy

Quality is the level of goodness of something or a certain degree, and the degree / level / quality stops both the standard of work, proper use and on schedule (On Schedule)

2. Quantity Accuracy

Quantity is the result of data processing and the numbers that become information material. Understanding quantity intended work results in accordance with the expected target in accordance with work location, volume, as well as in accordance with the needs in the work environment.

3. Timeliness

Timing is an indispensable source of management, so it must be carefully calculated. Preparation of schedule or schedule is one of the ways that can be used in accordance with the procedures, targets to be achieved, as well as seen from the many requests stakeholders.

The link between coordination and service effectiveness put forward by Terry in Hasibuan (2003: 80) is as follows: Coordination is a synchronous or orderly effort to provide the right amount and timing, and direct the execution to produce a uniform and harmonious action on a given target.

The coordination and effectiveness of the service has a close relationship as proposed by Sugandha (2006: 41) as follows: "In order for an organization or government administration to have effective work, every human activity must be coordinated". The component of understanding of goal optimization, ie the effectiveness of service is judged by the measure of how far an organization achieves a reasonable goal, rather than using its intended end or desired goal, as a basis for measurement. Based on the literature review and the above frame of mind can be described in the paradigm of research thinking as follows:

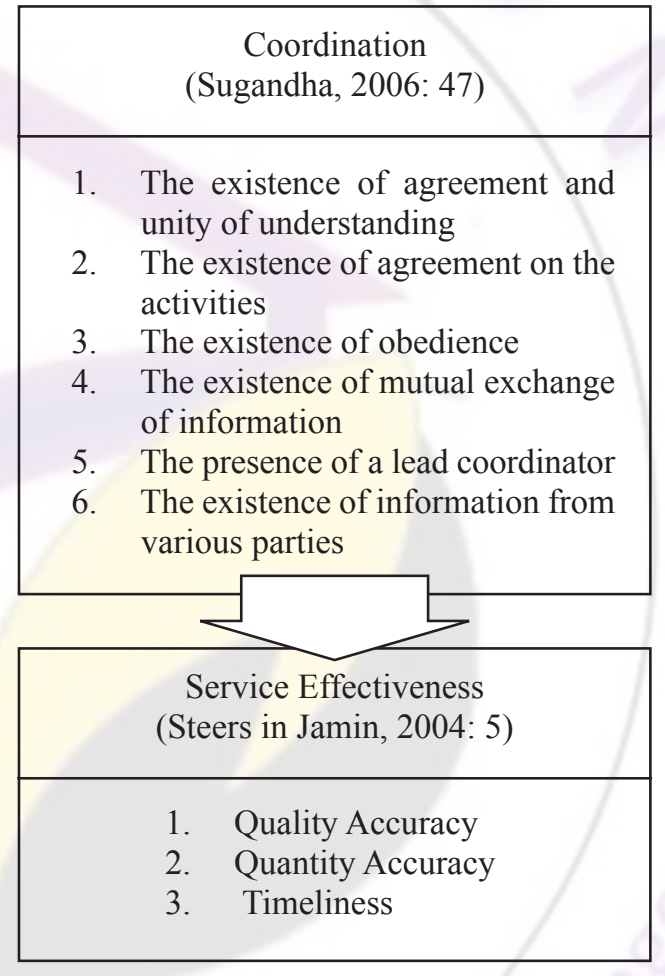

Figure 1. Framework Paradigm

\section{Method}

Based on the above mentioned background which becomes the problem statement (problem statement) is the effectiveness of One Stop PandeglangBanten Province Administration System low. Based on the statement of the problem can be formulated problem question(problem question) identified that is "How much Impact Coordination on Service Effectiveness of Pandeglang Area Manunggal One Roof Administration System of Banten Province? 


\subsection{Objectives Research}

1. Analyzing the magnitude of Impact Coordination on Service Effectiveness of Pandeglang Area Manunggal One Roof Administration System of Banten Province;

2. Develop the concept of coordination and service effectiveness of Pandeglang Area Manunggal One Roof Administration System of Banten Province

3. Applying theoretically the coordination in improving the effectiveness of Pandeglang Area Manunggal One Roof Administration System of Banten Province

\subsection{Usefulness Research}

1. Theoretical use of this research is expected to contribute the study of Public Administration Science and Public Policy.

2. Practical Use of this research is to be contributed in the form of suggestions to be input for all parties involved in the aspect of service at Samsat Office, so that the optimization and effectiveness of one-stop administrative service system Pandeglang Region Banten Province can be implemented properly.

\subsection{Hypothesis Research}

Based on the above framework, the researcher formulates the main hypothesis is: The major coordination of its impact on the effectiveness of Pandeglang Area ManunggalOneRoofAdministrationSystem of Banten Province.

\subsection{Object Of Research}

This research is done at the office of Pandeglang Area Manunggal One Roof Administration System of Banten Province.The position of the Technical Implementing Unit of the Service at the Provincial Finance and Asset Management Agency based on Banten Governor Regulation no. 65 Year 2008. Based on the Regulation of the Governor of Banten Number 65 Year 2009 on the Details of Duties and Functions of the Technical Implementation Unit of the Office at the Provincial Finance and Asset
Management Office of Banten, has the main duty to implement some of the functions of the service in the field of regional revenue services.

Duties and functions of Technical Implementation of UnitHead of Administration System Single Manpower Office Pandeglang Banten Province has the main duty to assist the Head of Office in carrying out government affairs in the field of technical operations of financial management and regional assets. In performing this basic task the Unit Head has the following functions:

a. To prepare operational technical plan in the field of management and service of Provincial Tax;

b. Implementation of operational technical policy in the field of management and service of Provincial Tax;

c. Implementation of registration, establishment and collection of provincial taxes;

d. Implementation of bookkeeping and reporting:

e. Implementation of administrative affairs;

f. Implementation of other tasks assigned by the Head of Service in accordance with the duties and functions.

In carrying out its function, Head Unit has job description as the following:

a. Develop UPT work plan;

b. Compile and define UPT technical operational plan;

c. To organize the supervision, control and supervision of UPT activities;

d. Implement coordination with related institutions;

e. Direct the tasks of subordinates in accordance with their duties both orally and in writing in order to smooth the execution of tasks;

f. Coordinate and facilitate activities at UPT;

g. Evaluate the implementation of UPT activities:

h. Implement monitoring, evaluation and performance appraisal performance of subordinate tasks on a regular basis through the scoring system available as a reflection of performance appraisal:

i. Compile and submit reports on the implementation of duties to superiors;

j. Present advice and consideration to superiors; 
k. Implementing technical policies in the field of income and utilization of assets in accordance with applicable provisions;

1. Managing general administrative affairs, equipment and housekeeping, managing personnel and financial administration;

m. Carry out the management of tax documents and other income;

n. Carry out other tasks according to their duties and functions.

\subsection{Research Methods}

The research method used in this research is descriptive analysis. Descriptive analysis according to Sugiyono (2000: 20) is "a method that describes an ongoing state at the time of the study, and how it affects". The data set were analyzed and compared to the existing theory and the problems that existed to draw conclusions. Research design according to Sugiyono (2002: 86) is explaining various variables to be studied, then make the relationship between one variable with other variables, so it will be easy to formulate research problems, theory selection, hypothesis formulation, research methods, research instruments, Expected conclusion ".

1. Data Collection Technique

a. Library study

b. Field Study

1) Non-participant observation

2) Interview

3) Questionnaire

2. Population Research

The population of his research is at the office of Administration System Single Manner One Roof Area Pandeglang Banten Province. Determine the respondents with census technique that is all employees at UPT One Man Administration System One Roof Area Pandeglang Banten Province, consisting and employees Dispenda 15 people, Police officers 7 people and employees Jasaraharja 5 people, totaling 27 people with details in the following table.
Table 1. Research Respondents

\begin{tabular}{lll}
\hline Number & \multicolumn{1}{c}{ Instance } & \multicolumn{1}{c}{ Amount } \\
\hline 1 & Employee Dispenda & 15 people \\
2 & Employee Police & 7 people \\
3 & Employee Jasaraharja & 5 people \\
\hline & Total & 27 people \\
\hline
\end{tabular}

Source: Single One Roof Administration System, Pandeglang Area of Banten Province, 2016.

\section{Data Analysis Techniques}

Statistical analysis in the opinion of Danim (1997: 27) "is used in carrying out the whole series of work of this study, including formulating hypotheses, preparing research instruments, determining samples, data analysis and last a conclusion and research results. Hypothesis Testing Design, Hypothesis test design in this study using Path Analysis (Path Analisys), as in the following picture

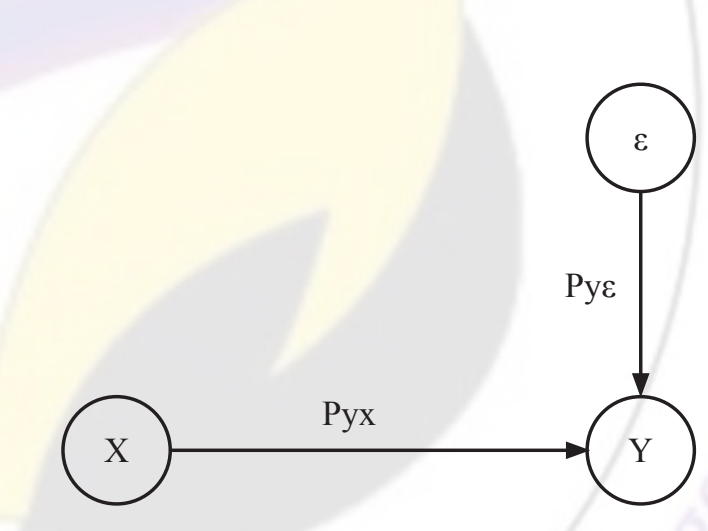

Figure 2. Influence Structure X against $\mathrm{Y}$

\section{Results and Discussion}

In the structure of the variables $\mathrm{X}$ to $\mathrm{Y}$ tested how much the impact of coordination variables on service effectiveness variables. The analysis method used is Path Analysis. The Path Analysis results are described as follows: 
Table 2.

Multiple Correlation Coefficient

\begin{tabular}{lllll}
\multicolumn{5}{c}{ Summary Model } \\
\hline Model & $\mathrm{R}$ & $\mathrm{R}$ & Adjusted & $\begin{array}{l}\text { Std. } \\
\text { Square } \\
\end{array}$ \\
& & & & $\begin{array}{l}\text { Rrror } \\
\text { Of the } \\
\text { Estimat }\end{array}$ \\
\hline 1 & $.990^{\mathrm{a}}$ & .982 & .980 & 2.65570 \\
\hline
\end{tabular}

a. Predictors: (Constant), $\mathrm{x}$

The table above shows the value of determination coefficient (R2) of 0.980 means that $98.0 \%$ variability of employee service effectiveness can be explained by independent variables in this case coordination, which also can be interpreted that there is damage coordination to effectiveness of employee service coefficient determination $(\mathrm{R} 2=98.0 \%$ ) Or $98.0 \%$ can also be interpreted that the influence of variables outside the model that is equal to py, $=1-\mathrm{R} 2=0.02$ (error). The magnitude of the path coefficient for each variable is as follows:

Table 3.

Standardized Coefficients Values For Path Coefficients Coefficients $^{\mathrm{a}}$

\begin{tabular}{|c|c|c|c|c|c|}
\hline \multicolumn{6}{|c|}{ Coefficients $^{\mathrm{a}}$} \\
\hline Model & $\begin{array}{r}\text { Unstanc } \\
\text { Coeff }\end{array}$ & $\begin{array}{l}\text { ardized } \\
\text { cients }\end{array}$ & $\begin{array}{c}\text { Unstandardized } \\
\text { Coefficients }\end{array}$ & \multirow{2}{*}{$\mathrm{t}$} & \multirow{2}{*}{ Sig. } \\
\hline & B & $\begin{array}{l}\text { Std. } \\
\text { Error }\end{array}$ & Beta & & \\
\hline 1 & 12.952 & 3.863 & & 3.352 & .003 \\
\hline $\begin{array}{l}\text { Constant } \\
\mathrm{X}\end{array}$ & .174 & .073 & .990 & 2.392 & .025 \\
\hline
\end{tabular}

a. Dependent Variable: y

The table describes the value of standaridized cofficiients or path coefficients of coordination variables to service effectiveness variables, ie path coefficients from $\mathrm{X}$ to $\mathrm{Y}=0.990$. The results of data processing can be made in the form of lane diagrams and structural equation by including the estimated coefficient of data processing results, then the structural equation is:

$\mathrm{Y}=131 \mathrm{X}+$

$\mathrm{Y}=0.990 \mathrm{X}+\mathrm{s}$
Where :

$\mathrm{X}=$ Coordinate

$\mathrm{Y}=$ Effectiveness of employee

$€=$ Epsilon

Referring to the table of multiple correlation coefficients for the structures tested showed multiple coefficient of determination and all exogenous variables tested were $=98.0 \%$. This multiple determination value is the square of the multiple correlation coefficient value $\mathrm{R}=$ 0.990 . This $\mathrm{R} 2$ value indicates that the degree of influence of coordination is very closely when compared with other variables that are not examined. Based on the path coefficient values, it can then be calculated that the magnitude of the effect of the variables $\mathrm{X}$ to $\mathrm{Y}$ is 0.980 which is the square of the coefficient value $\mathrm{R}=0.990$, While the magnitude of the influence of other variables that are not researched is 0.02 , for more details can be seen in the picture below

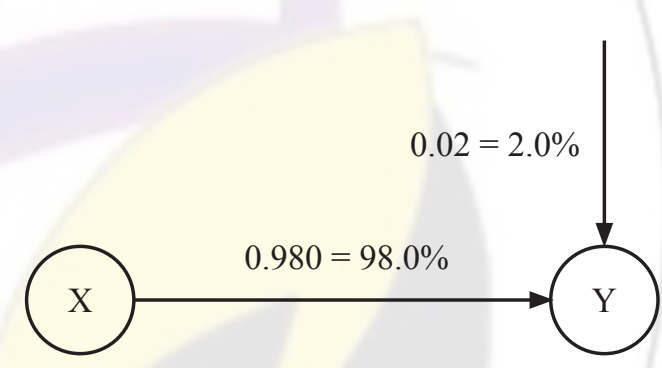

Figure 3. The magnitude of the impact of variable $\mathrm{X}$ to $\mathrm{Y}$

The magnitude of the impact of the coordination variable on service effectiveness can be explained as follows:

\subsection{Impact of Coordination (X) on Service Effectiveness (Y)}

Based on the results of analysis of influence contribution test, indicating that the coordination variables affect the effectiveness of service is equal to 0.980 or $98.0 \%$. Coordination consisting of elements of the existence of understanding and unity of understanding, the existence of agreement emngenai activities, the existence of compliance, the existence of information exchange, the coordinator who 
can lead, the infoemasi from various parties and the existence of sating honor strongly affects the effectiveness of employees consisting of aspects Accuracy of quality, accuracy of quantity and timeliness.

\subsection{Impact of Other Variables (s) on Service Effectiveness ( $Y$ )}

Coordination consisting of elements of the concept and unity of understanding, the existence of agreement on the activities, the existence of compliance, the existence of exchange information, the coordinator who can lead, the information from various parties and the existence of respecting singk affects the effectiveness of services of $98.0 \%$, while the rest of Of $2.0 \%$ influenced by other variables not examined in this study.

Based on the above statistical calculation results can be researcher that the coordination factor is one important part in facilitating

The achievement of organizational goals. Many facts indicate a failure experienced by an organization caused by one of them by the lack of coordination factors. In this case One Man Administration System One Roof Area Pandeglang Banten Province consider the importance of coordination factor in supporting the effectiveness of employee, especially in handling motor vehicle tax.

The results of statistical tests illustrate that quantitatively the coordination variables have an effect on the effectiveness of employees in the development and management of irrigation systems in the Single Administrative System One Roof Area Pandeglang Banten Province of $98.0 \%$. The result of the test shows that the research hypothesis which reads -Coordination of its influence on the effectiveness of the employee staff of SingleRoof Administration System of Pandeglang Region of Banten Province "can be accepted empirically. The test results reflect that the contribution of coordination, according to the above statistical test results positively and Significant to the effectiveness of employee work.Therefore, it is necessary to optimize the implementation of coordination in the environment Administration System
Manunggal Satu Map Pandeglang Region Banten Province

The results of the study found that the policy made by the One Manpower Administration System One Roof Area Pandeglang Banten Province, empirically has reflected the suitability between responsibilities and functions of each section in accordance with the main tasks and functions that have been determined. The suitability of responsibilities and functions is, in fact, one of the conditions in supporting the achievement of organizational goals. The factual condition shows the importance of the aspect of the responsibilities of the employees in the environment of OneStop Manunggal One System of Pandeglang Region of Banten Province. This is in line with Hasibuan's view (1996: 168) which stipulates that "in order to streamline the achievement of organizational objectives, the leadership should cultivate a sense of responsibility for his employees ...".

Coordination is a step taken by the leader in the Administration System Manunggal One Roof Area Pandeglang Banten Province in order to support the smooth implementation of coordination that has been determined. In that context, the extent to which the head of the office is able to communicate these aspects of coordination effectively to every employee in the workplace, so that the Institutional Administration System One Manent One Roof Pandeglang Banten Province can translate various programs of activities effectively in accordance with the policy objectives that have been Set.

The findings above, further strengthen the argument that the coordination factor in the Single Administrative System One Roof Area Pandeglang Banten Province, plays a very important role in realizing the effectiveness of employees. This implies that the effectiveness of work achieved by employees empirically does require an appropriate coordination pattern, so that they can truly understand every process of activity that has been established by the One Stop Pandeglang Regional Single Administration System of Banten Province. The emergence of misconceptions about procedures imposed by the implementing 
officers may be caused by the inaccuracy of the leadership in coordinating the procedures to be performed by the employees. Thus, it can be said that the coordinates

The results also reveal that the success rate of coordination in improving the effectiveness of employees is not only determined by the accuracy in coordinating the activity, but also determined by the existence clarity in coordinating aspects related to coordination itself. Understandably, karma accuracy in coordinating coordination aspects is, in fact, a key factor in understanding coordination as a whole. Therefore, clarity in coordinating aspects of coordination is also an important part to note.

The above findings are also based on the argument that the lack of clarity in coordination in Pandeglang Banten Province One Roof Administration System, will undoubtedly result in a misunderstanding of the essence of coordination. Errors in interpreting the essence of coordination to be implemented will certainly affect the success rate of the implementation of the work program that has been established. Further implications caused by mistakes in interpreting the essence of coordination will lead to mis-interpretation and misunderstanding of the goals and objectives that have been set. Even the tendency, it could lead to a multi interpretation of the executing officers and parties involved in the environment One-Stop Administration System Pandeglang Region Banten Province.

The results of the study found that the leadership ability in coordinating various activities within the One Man Administration System One Roof Area Pandeglang Banten Province is one important and strategic factors in supporting the effectiveness of employees. The strategic position of this coordination can be understood, because through the coordination of various activities that will be carried out by the One Manpower Administration System One Roof Area Pandeglang Banten Province will have clarity and can foster harmonization among the parties involved. Operationally, coordination can be divided into two categories, namely internal and external coordination. Internal coordination can be classified in vertical coordination and coordination of a horizontal nature.

Coordination that is vertical is done between the apparatus that exist in the environment of One Manunggal One Roof System Area Pandeglang Banten Province. Then coordination that is horizontal, ie coordination between the parts in the environment OneRoof Administration System One Roof Area Pandeglang Banten Province which position level. While the coordination of an external nature, namely coordination between the Single Administrative System One Roof Area Pandeglang Banten province with other agencies, both existing within the Provincial Government and other agencies. Therefore, in order to streamline the execution of existing work within the Single Administration System One Roof Area Pandeglang Banten Province, leaders are required to have the commitment and serious attention to the implementation of coordination, both internally and externally.

Urgency implementation of coordination by the leadership as disclosed above is based on the idea that the effectiveness of employees in the environment One-Roof Administration System One Pandeglang Region Banten Province one of them is determined by the ability of leaders in coordinating various activities related to the main tasks and functions of each employee. Strengthening of the view is based on the argument that the success of an organization, among others, determined the ability of leaders in menyatupadukan activities of each organization that affect each other with different levels of influence. This view suggests that effective coordination among the various components involved in the implementation of the main tasks and functions will encourage the creation of a conducive climate in order to realize the goals that have been set.The importance of building this effective coordination is also inspired by the idea that each organization has different characteristics, requiring a common vision, mission and perception in translating the various tasks and tasks that have been provided byPandeglangArea Manunggal One Roof Administration System of Banten Province. 


\section{Conclusions}

Based on the results of the research analysis as described in the previous wetting, the researcher can conclude comprehensively the result of the research is that the coordination has had a very big and significant impact on the effectiveness of the service of motor vehicle registration number at the offices ofPandeglang Area ManunggalOne Roof Administration System of Banten Province. This implies that coordination is very influential and very important to be implemented so that the effectiveness of service can run as expected of the organization. The results of the study also found that the effectiveness of services at the offices of the Pandeglang Area ManunggalOne Roof Administration System of Banten Province.is not only influenced by mere coordination variables, but also influenced by other factors in the research methodology referred to as epsilon (s).

Based on the research findings, researchers can provide research suggestions that are expected to be made as a recommendation, both in the context of the development of science and the contribution to the improvement of the concept of control for related institutions. The suggestions include:

1. Academic Suggestions

It is necessary to conduct further research on the phenomenon of low effectiveness of service at the office of Administration System Manunggal One Roof Pandeglang Region of Banten Province is associated with coordination variables from different perspectives, especially from the perspective of public policy science.

2. Practical Tips

a. There needs to be a more comprehensive understanding of the concept of coordination, especially concerning the element of obedience, in order to indicate the ineffectiveness of service at the Office of Pandeglang Area ManunggalOne Roof Administration System of as much as possible can be anticipated and dieleminir,

b. To improve the work discipline of the employees within the Single Administrative System System of
One Roof of Pandeglang Region of Banten Province, the leader should be more assertive, rational and persuasive conduct disciplinary action so that the employees who perform the disciplinary action are deterred and motivated to not make similar mistakes,

c. In order to improve the capability of the dava source of apparatus, the Office of Pandeglang Area ManunggalOne Roof Administration System of Banten Provinceis suggested to give more opportunity to the employees to follow the employee development program.

\section{Reference}

\section{Books:}

Gibson. 1994. Organisasi dan Manajemen. Jakarta : PT Toko Gunung Agung.

Hasibuan, Malayu S.P. 2003. Manajemen Sumber Daya Manusia. Edisi ke-2. Jakarta : Erlangga.

Kaloh, Johanis. 1995. Konsep Koordinasi Dalam Proses Administrasi Suatu Tinjauan Dan Sudut Administrasi Pemerintahan. Jakarta : Yayasan Karya Dharma HP.

Mangkunegara, Anwar Prabu. 2004. Manajemen Sumber Daya Manusia Perusahaan. Bandung : PT. Remaja Rosdakarya.

Moenir, AS. 2002. Manajemen Pelayanan Umum di Indonesia. Bandung : Bumi Aksara.

Permata, Agus. 1997. Manajemen Pelayanan Masyarakat. Bandung : AlfaBeta.

Robbins, Stephen, P. 2004. Teori Organisasi : Struktur, Desain dan Aplikasi. Ed. 3 Alih Bahasa : Jusuf Udava. Jakarta : Arcan.

Sulastiono,Agus. 1996.Manajemen Pelayanan Masyarakat. Bandung : AlfaBeta Soetopo. 1999. Pelayanan Prima. Bandung : CV. Mandar Maju.

Sugandha, Dann. 2006. Koordinasi Alat Pemersatu Gerak Administrasi. Jakarta : Intermedia. 
Sugiyono. 2002. Metode Penelitian Administrasi. Bandung : AlfaBeta.

Steers, Richard. 1994. Elektivitas Organisasi. Alih Bahasa: Magdalena Jamin. Jakarta : Ghalia Indonesia.

Syafrudin, Ateng. 1993. Pengaturan Koordinasi Pemerintahan di Daerah. cet. 2 Bandung : PT. Citra Aditya Bakti.

Terry, George, R. 2003. Prinsip-Prinsip Manajemen. Penerjemah : J. Smith. D.F.M. Jakarta : PT. Bumi Akasara

Tjiptono, Fandi. 1996. Manajemen Jasa. Yogyakarta : Andi.

Wasistiono, Sadu. 2003. Manajemen Pemerintahan Daerah. Bandung : Fokus Media.

Documents :

Undang-undang Nomor 24Tahun 2014 tentang Pemerintahan Daerah.

Undang-undang Nomor 33 Tahun 2004 tentang Perimbangan Keuangan antara Pemerintahan Pusat dan Daerah

Peraturan Daerah Propinsi Jawa Barat Nomor 7 Tahun 2001 tentang Pajak Kendaraan Bermotor
Keputusan Gubernur Jawa Barat Nomor 12 Tahun 2002 tentang Petunjuk Pelaksanaan Peraturan Daerah Propinsi Jawa Barat Nomor 7 Tahun 2001

Keputusan Gubernur Jawa Barat Nomor 65 Tahun 2002 tentang tugas pokok, Fungsi dan Rincian tugas pada Unit Pelaksana Teknis Dinas di Lingkungan Dinas Pendapatan Propinsi Jawa Barat

Wiig, M., Karl, (2002),-Knowledge Management in Public Administration" Journal of Knowledge Management, Vol.6 (3), 224-239.

Akinboade, Akinloye., Oludele, Kinfack., Chaneline., Emilie, Mokwena, Putuma., Mandisa. 2012. An Analysis of Citizen Satisfaction with Public Service Delivery in the District Municipality of South Africa. International Journal of Social Economics. Vol. 39 (3), 182-199.

United Nation Development Program, (2015)," From Old Public Adminitration to the New Public Service. Implications for Public Sector Reform in Developing Countries ", The Global Centre for Public Service Excellence, Singapore 